\title{
Guidelines for Bystander First Aid 2016
}

Jen Heng Pek, MBBs, MMed

ABSTRACT Cardiac life support is a form of first aid for cardiac emergencies. However, research and evidence in this field is lacking compared with other forms of first aid. Having identified the common emergencies that are encountered in the hospital, based on the available evidence, we have put together what could be an evidence-based approach to the first aid management of some of these common emergencies, viz. breathlessness, chest pain, allergies, stroke, heat injury, poisoning, unconsciousness, seizures, and trauma situations such as bleeding, wounds, contusions, head injury, burns and fractures. Educating the public is the key to developing a first responder bystander. These guidelines could become the basis for training of the public.

Keywords: breathlessness, chest pain, seizures, stroke, trauma first aid

\section{INTRODUCTION}

First aid, as defined by the International Liaison Committee on Resuscitation (ILCOR) First Aid Task Force in 2015, is the helping behaviours and initial care provided for an acute illness or injury. ${ }^{(1)}$ It can be initiated by anyone to preserve life, alleviate suffering, limit further injury and/or promote recovery in any situation. For first aid to be effective and safe, the provider needs to recognise and assess the injury or illness before performing immediate medical intervention while simultaneously activating prehospital emergency services as required. Training is necessary to equip the first aid provider with the knowledge, skill and confidence to attend to an emergency.

\section{SCOPE OF THE PROBLEM}

Unintentional injury is the fifth leading cause of death ${ }^{(2)}$ (Table I) and the top cause of hospitalisation ${ }^{(3)}$ (Table II) in Singapore. Along with acute medical emergencies such as myocardial infarction and stroke, this makes up a significant number of casualties who will benefit from timely interventions. First aid measures such as basic life support, including cardiopulmonary resuscitation, recognition of myocardial infarct and stroke, and controlling haemorrhage, can be life-saving. Given the paucity of research in the field of first aid, local data on the frequency and effectiveness of first aid interventions is limited.

In Singapore, a variety of first aid courses (e.g. Basic First Aid, Standard First Aid with or without Automated External Defibrillator [AED], Adult First Aid, Child First Aid) are conducted by training centres for interested participants. The National First Aid Council (NFAC) only accredits the Standard First Aid with AED course (mandated by the National Registry of Coaches or the Singapore Sports Council for sports coaches) and the Child First Aid course (mandated by the Early Childhood Development Agency under the Ministry of Social and Family Development for infant/childcare personnel). Although NFAC provides the accreditation framework ${ }^{(4)}$ for the overall content, and the conduct and assessment of the course, training centres are allowed to use their own training materials and methods. This framework was last updated in 2013 by NFAC council members who were representatives of the National Resuscitation Council, National Trades Union Congress, People's Association, Singapore Civil Defence Force, Singapore Red Cross Society and St John Ambulance Brigade.

The Occupational First Aid Course is a Ministry of Manpower (MOM)-accredited course for appointed providers at the workplace, in accordance with Workplace Safety and Health (First-Aid) Regulations. ${ }^{(5)}$ In 2015, the Workplace Safety and Health Council, MOM, last updated the reference guidelines ${ }^{(6)}$ for the overall course contents, learning objectives, and the conduct and assessment of the course. The courseware developers that the learning service providers (LSPs) engaged are allowed to use reference materials to develop the learning objectives, and no specific method of instruction is prescribed. The LSPs are certified to offer the course by an appointed certification body accredited by the Singapore Accreditation Council under the ISO 29990:2010 LSP scheme.

\section{THE EVIDENCE}

The International First Aid Science Advisory Board last evaluated the scientific literature on first aid and published the treatment recommendations in 2010. ${ }^{(7)}$ In 2015, the First Aid Task Force from ILCOR released the International Consensus on First Aid Science with Treatment Recommendations (CoSTR) after completing a comprehensive review using the Grading of Recommendations, Assessment, Development and Evaluation (i.e. GRADE) methodology in combination with ILCOR's Scientific Evidence Evaluation and Review System (SEERS). The final recommendations on guidelines for bystander first aid in this paper were derived after a review of these consensus statements ${ }^{(8)}$ and the relevant literature, giving due consideration to local practice.

\section{BYSTANDER FIRST AID GUIDELINES General principles \\ Practice of first aid}

At any level of training, first aid competencies ${ }^{(9)}$ should include: (a) early recognition, assessment and prioritisation of the need 
Table I. Principal causes of death in Singapore. ${ }^{(2)}$

\begin{tabular}{|c|c|c|c|}
\hline Principal cause of death & 2012 & 2013 & 2014 \\
\hline Total no. of deaths & 18,481 & 18,938 & 19,393 \\
\hline 1. Cancer & 30.1 & 30.5 & 29.4 \\
\hline 2. Pneumonia & 16.8 & 18.5 & 19.0 \\
\hline 3. Ischaemic heart diseases & 16.1 & 15.5 & 16.0 \\
\hline $\begin{array}{l}\text { 4. Cerebrovascular diseases } \\
\text { (including stroke) }\end{array}$ & 9.3 & 8.9 & 8.4 \\
\hline $\begin{array}{l}\text { 5. External causes of morbidity } \\
\text { and mortality }\end{array}$ & 5.6 & 4.9 & 4.7 \\
\hline $\begin{array}{l}\text { 6. Hypertensive diseases } \\
\text { (including hypertensive heart } \\
\text { disease) }\end{array}$ & 2.8 & 3.1 & 3.6 \\
\hline 7. Urinary tract infection & 2.4 & 2.6 & 2.6 \\
\hline $\begin{array}{l}\text { 8. Nephritis, nephrotic syndrome } \\
\text { and nephrosis }\end{array}$ & 2.4 & 2.4 & 2.0 \\
\hline 9. Other heart diseases & 1.9 & 2.0 & 1.9 \\
\hline $\begin{array}{l}\text { 10. Chronic obstructive lung } \\
\text { disease }\end{array}$ & 2.1 & 1.6 & 1.8 \\
\hline
\end{tabular}

Data presented as percentage of total deaths, unless otherwise stated.

Table II. Top ten conditions requiring hospitalisation in Singapore. ${ }^{(3)}$

\begin{tabular}{|c|c|c|c|}
\hline Condition requiring hospitalisation & 2012 & 2013 & 2014 \\
\hline Total no. of discharges ('000) & 476.1 & 491.0 & 507.8 \\
\hline 1. Accident, poisoning and violence & 8.3 & 8.4 & 8.4 \\
\hline 2. Cancer & 6.0 & 5.9 & 6.0 \\
\hline 3. Ischaemic heart diseases & 3.6 & 3.5 & 3.3 \\
\hline 4. Intestinal infectious diseases & 2.9 & 2.7 & 2.8 \\
\hline 5. Pneumonia & 2.8 & 2.7 & 2.8 \\
\hline 6. Other heart diseases & 2.6 & 2.7 & 2.7 \\
\hline $\begin{array}{l}\text { 7. Obstetric complications affecting } \\
\text { fetus and newborn }\end{array}$ & 2.3 & 2.2 & 2.1 \\
\hline 8. Diabetes mellitus & 1.8 & 2.0 & 2.0 \\
\hline $\begin{array}{l}\text { 9. Infections of the skin and } \\
\text { subcutaneous tissue }\end{array}$ & 2.0 & 2.0 & 1.9 \\
\hline $\begin{array}{l}\text { 10. Cerebrovascular diseases } \\
\text { (including stroke) }\end{array}$ & 1.8 & 1.8 & 1.9 \\
\hline
\end{tabular}

Data presented as percentage of total discharges, unless otherwise stated.

for first aid; (b) provision of care with appropriate knowledge, skill and behaviour; and (c) awareness of limitations and seeking additional help without delay.

\section{Safety - scene and personal}

The first aid provider must always assess the situation to make sure it is safe before proceeding to assist the casualty. There must be an ongoing awareness of potential hazards. If there are dangers that cannot be mitigated, the provider should stay clear and activate the prehospital emergency services. Occasionally, the situation may allow for the casualty to be moved to a safe location before providing first aid. This should not be attempted if the movement can worsen the condition of the casualty.

Proper personal protective equipment (PPE) should be used, and universal precautions exercised to minimise unnecessary exposure and harm to the provider. While PPE might not be available to bystanders, the following should be practised whenever possible: (a) wash hands before and after attending to the casualty; (b) wear gloves, face mask, eye protection and/or full gown if coming in contact with blood or other body fluids or tissues; and (c) proper disposal of all contaminated PPE after use.

\section{First aid kit}

A first aid kit contains a collection of supplies and equipment that may be used when providing first aid. As the kit may be tailored according to individual or organisational needs, the contents may vary widely. We recommend that every home should have a first aid kit containing, at the minimum, the following: resuscitation mask (pocket mask or face shield); sterile water or saline in $100 \mathrm{~mL}$ disposable container; adhesive dressings (band-aids, sticking plasters); absorbent gauze; eye pad; crepe bandage $(5 \mathrm{~cm}, 10 \mathrm{~cm}, 15 \mathrm{~cm})$; triangular bandages; hypoallergenic tape; safety pins; tweezer; scissors; torchlight; antiseptic wipes; and disposable gloves. Supplementary supplies such as medications, structural aluminium malleable splint, eye shield, pulse oximeter and glucose meter may be included depending on the purpose of use for specialised first aid kits. All first aid kits should be checked regularly and expired contents replaced.

\section{Specific conditions}

The first aid topics from COSTR were reviewed and conditions relevant to Singapore's context have been selected for inclusion in this section. The following guidelines were made based on the 'minimal or no equipment' approach, as is the case in most instances of bystander first aid. The conduct of first aid courses would be dependent on the specific needs of the target populations and the first aid programmes.

\section{Medical}

(a) Breathing difficulties: Many medical problems can result in breathing difficulties. These include asthma, chronic bronchitis and heart failure. For asthma and chronic bronchitis, proper use of inhaled bronchodilators can relieve shortness of breath and wheeze. They have been shown to be effective, ${ }^{(10-20)}$ with a low incidence of adverse events. ${ }^{(10,15-17)}$ Therefore, first aid providers should be familiar with the available inhaled bronchodilator and assist when a casualty with asthma or chronic bronchitis is experiencing an acute exacerbation of the condition. For patients with heart failure, the upright position is associated with less breathing distress than the supine position. In addition, restricting blood flow to the heart helps to reduce myocardial workload in such patients. This can be achieved by flexing both knees of the patient and maintaining them in that position with a pillow. Patients with bronchial asthma or chronic bronchitis are also better managed in the upright rather than the supine position. Therefore, have the patient seated upright with his knees flexed. There is no evidence for or against routine administration of supplementary oxygen by 
first aid providers. ${ }^{(8)}$ However, as oxygen is not always available and specific training in its use is required, we do not consider it a standard first aid skill.

(b) Anaphylaxis: A small proportion of allergic reactions can progress to anaphylaxis, necessitating the use of adrenaline. Persons at risk are prescribed and carry their own adrenaline auto-injector. The first aid provider may assist persons with anaphylaxis to administer their own adrenaline or administer it for them, ${ }^{(7)}$ and thereafter proceed to activate the emergency ambulance. While a second dose of adrenaline is beneficial ${ }^{(21-29)}$ for persons without an initial response to the first dose, we recommend the repeat dose be left to the emergency ambulance provider or physician.

(c) Chest pain: There are many causes of chest pain - from minor costochondritis to severe myocardial infarction which can be difficult to differentiate. When transferring anyone with chest pain to a healthcare facility, one should immediately activate the emergency ambulance services instead of arranging for private transportation. While early aspirin use can decrease mortality due to myocardial infarction, ${ }^{(30-32)}$ we recommend the decision to administer aspirin to be left to the emergency ambulance provider or physician, since there is a need to ask about aspirin allergy before drug administration.

(d) Shock: Passive leg raise of the feet to about $30^{\circ}-60^{\circ}$ from the supine position can lead to temporary improvement in vital signs and cardiac output with no reported adverse effect. ${ }^{(33,34)}$ This option can be considered while awaiting the arrival of the emergency ambulance, unless the movement causes pain.

(e) Unresponsiveness: If a casualty is unresponsive and not breathing normally, the provider should proceed according to the basic life support guidelines immediately. This is addressed in Lim et al's Basic Cardiac Life Support: 2016 Singapore Guidelines. ${ }^{(35)}$ An unresponsive casualty who is breathing normally should be positioned in a lateral, side-lying recovery position as opposed to the supine position. This position involves extending one of the arms of the person above the head and rolling the body to the side so that the person's head rests on the extended arm. Once on the side, bend both legs to stabilise the body. This will increase total airway volume ${ }^{(36)}$ and decrease stridor severity. ${ }^{(37)}$ However, if a neck, back, hip or pelvic injury is suspected, the casualty should be left in the position he was found in to avoid further potential injury, unless there is a need to open the airway or to reach a safe location.

(f) Stroke: Early recognition of stroke using stroke assessment systems can decrease the time interval between onset and arrival at hospital for definitive treatment, leading to improved functional outcomes. ${ }^{(38-43)}$ First aid providers should be trained in the use of stroke assessment systems to recognise the signs and symptoms of stroke. We recommend the use of the FAST (Face, Arm, Speech, Time) stroke assessment system, which is the simplest tool for bystanders, with high sensitivity for the identification of stroke. ${ }^{(8)}$ 'Face' refers to facial asymmetry, 'arm' to weakness of one arm or leg, and 'speech' to slurring of speech.

(g) Seizure: During a seizure, the first aid provider's goal is to ensure airway patency and to prevent injury. ${ }^{(7)}$ The casualty should be kept in a left lateral position. Avoid placing any object in the casualty's mouth, as it can cause dental damage or aspiration. Unnecessary restraining during a seizure may result in musculoskeletal injury. Activate the emergency ambulance and continue to monitor the casualty, who may be unresponsive or confused for a period after the seizure.

(h) Hypoglycaemia: Diabetics who display symptoms of hypoglycaemia, such as tremors, diaphoresis and confusion, should be assumed to have hypoglycaemia. The emergency ambulance should be activated immediately if the casualty is unconscious, having a seizure, or is unable to follow simple commands or swallow safely. If the casualty is able to follow simple commands and to swallow safely, oral glucose or other dietary sugars can be used to effectively resolve hypoglycaemia. ${ }^{(4-47)}$ The first aid provider should monitor for resolution within the next 10-15 minutes. The emergency ambulance service should be activated if there is deterioration or persistence of symptoms.

(i) Exertional dehydration: Heat cramps, heat exhaustion and heat stroke are often precipitated by vigorous exercise in a hot and humid environment. Heat cramps are involuntary muscle spasms affecting the calves, arms, abdominal muscles and back. First aid measures include rest, cooling of the body with water or drinking a carbohydrate-electrolyte solution (such as juice, milk or a commercial drink) and icing or stretching of the affected muscles. ${ }^{(48-57)}$ Potable water may be used if carbohydrate-electrolyte solutions are not readily available. ${ }^{(9)}$ Casualties with heat exhaustion may present with nausea, dizziness, muscle cramps, headache, fatigue and heavy sweating. Cooling measures should be initiated by moving the casualty to a cool place, removing his clothes, cooling with cool water spray and encouraging oral fluids. Heat stroke occurs when there is central nervous system involvement, presenting as syncope, confusion or seizures. The most important action for a victim of heat stroke is to begin immediate cooling and to activate the emergency ambulance to take the casualty to the hospital for advanced care. ${ }^{(7)}$ As casualties with heat stroke may not be able to swallow safely, one should not force them to drink.

(j) Ingested poisons: Limit further access to the poison by the casualty. Activate the emergency ambulance immediately and do not administer anything by mouth to a person who has ingested poison because it may be harmful. There is no evidence for the effectiveness of dilution with water or activated charcoal as a first aid measure. ${ }^{(7)}$

\section{Trauma}

(a) Bleeding: Control of bleeding is an important skill in first aid. Direct pressure is the best method. ${ }^{(58-64)}$ Firm pressure maintained for a prolonged duration is necessary for 
successful control of bleeding. If it is not possible to provide continuous manual pressure, wrap an elastic bandage over a gauze to hold it in place with pressure. ${ }^{(65-68)}$ The use of pressure points and elevation of an extremity to control bleeding are not indicated. ${ }^{(9)}$ While tourniquets ${ }^{(69-72)}$ and haemostatic dressings ${ }^{(73-76)}$ may be effective in controlling bleeding, we do not recommend their use for bystander first aid, as proper application requires sustained training.

(b) Wounds and abrasions: Irrigate the wound thoroughly with potable water to ensure that there is no foreign matter left within. Covering the wound subsequently with an antibiotic ointment and a clean occlusive dressing ${ }^{(77-79)}$ will allow wounds to heal better with less infection.

(c) Thermal burns: Cooling burns with cool or tepid potable water as soon as possible for at least ten minutes can reduce the risk and depth of injury. ${ }^{(80,81)}$ Avoid applying ice directly to a burn, as it can cause tissue ischaemia. Remove any constricting objects on the person such as watches, rings, bracelets and belts. After cooling of a burn, the area may be loosely covered with a sterile, dry dressing. The prehospital emergency ambulance service should be activated to take the casualty to advanced care when burns are associated with the following:(9) difficulty breathing; blistering or broken skin; involvement of the face, neck, hands or genitals; large surface area affected; and any other cause for concern.

(d) Electrical injury: After an electrical injury, a casualty can suffer from a range of conditions, from thermal burns to cardiac arrhythmias and respiratory arrest. Before first aid is provided, the power should be turned off at its source by the appropriate authorities, if it cannot be safely done by the provider. Assess the casualty and activate the emergency ambulance to take the casualty to the hospital, as the extent of injury may not be apparent. (7) $^{(7)}$

(e) Head injury: The signs and symptoms of head injury are varied and subtle. Significant head injury must be recognised by the first aid provider. Not doing so can have long-term adverse or even fatal consequences. ${ }^{(82)}$ Significant head injury can also be associated with spinal injury. Measures to ensure basic spinal protection should be in place. In addition, any bleeding from a head injury needs to be addressed by pressure dressings. The casualty would also need to be reviewed soon in a hospital setting to rule out any intracranial injury. Therefore, we recommend any person with a head injury that has resulted in a change of level of consciousness, with progressive development of headache, nausea, dizziness, unsteadiness, visual disturbance, confusion and amnesia (before or after the injury), be evacuated to a hospital for evaluation by a healthcare provider as soon as possible. ${ }^{(9)}$

(f) Spinal motion restriction: Spinal injury should be suspected in the following:(7) age $\geq 65$ years old; driver, passenger or pedestrian in a motor vehicle, motorcycle or bicycle crash; fall from greater than standing height; tingling in the extremities; pain or tenderness in the neck or back; sensory deficit or muscle weakness involving the torso or upper extremities; intoxicated or not fully alert; other painful distracting injuries, especially of the head and neck; and children $\geq 2$ years old with evidence of head or neck trauma. In such situations, we recommend that a first aid provider keeps the casualty as still as possible till the arrival of the prehospital emergency medical services. Manual inline immobilisation by the first aider may be used rather than a cervical collar. The application of cervical collars by first aid providers is discouraged, as the current literature shows more potential harm than benefit. ${ }^{(83-89)}$ Furthermore, it requires extensive training for proper application.

(g) Fractures and dislocations: When a fracture or dislocation is suspected, the first aid provider should not move or try to straighten the injured extremity. ${ }^{(9)}$ Open wounds should be covered with a dressing to minimise the likelihood of infection. Splinting of fractures with commonly available objects can be attempted to limit pain and further injury while allowing for prompt evacuation. The emergency ambulance must be activated immediately if the extremity is blue or pale.

(h) Sprains and strains: Joint sprains and muscle contusions can benefit from cold application with a plastic bag or damp cloth filled with a mixture of ice and water (better than ice alone). This can reduce haemorrhage, oedema, pain and disability. ${ }^{(90-95)}$ Application time $<20$ minutes and a barrier between the cold container and skin can help prevent cold injury. ${ }^{(7)}$

(i) Bites: Bites (human and animal) can be irrigated with copious amount of water to prevent bacterial infection. ${ }^{(96)}$ Snakebites may benefit from the application of a pressure immobilisation bandage around the entire length of the bitten extremity to decrease venom dissemination by slowing lymph flow. ${ }^{(7)}$ However, skill retention for proper application is poor among first aid providers. ${ }^{(97,98)}$ Therefore, we do not recommend routine application of the pressure immobilisation bandage, as inadequate pressure is ineffective and too much pressure can cause damage to local tissues. General immobilisation with a splint and triangular bandages may be an alternative. When a person has been stung by a jellyfish, the first aid provider needs to prevent further nematocyst discharge and provide pain relief to the casualty. Liberal washing with vinegar (4\%-6\% acetic acid solution) for at least 30 seconds can inactivate the venom and prevent further envenomation from nematocyst discharge. ${ }^{(99,100)}$ For pain relief, jellyfish sting should be treated with hot water immersion $\left(45^{\circ} \mathrm{C}\right.$ or as hot as tolerable) for at least 20 minutes or for as long as the pain persists. ${ }^{(101-104)}$

(j) Dental injuries: Seek rapid medical consultation following tooth avulsion. Immediate re-implantation of an avulsed tooth within an hour provides the greatest chance of tooth survival. ${ }^{(105)}$ While awaiting re-implantation, the avulsed tooth may be stored in egg white, coconut water, whole milk or the injured person's saliva (not mouth). ${ }^{(9)}$

(k) Drowning: The casualty should be removed from the water rapidly and safely. Assess the casualty immediately. 
If the casualty is unresponsive and not breathing normally and only one first aid provider is present, commence cardiopulmonary resuscitation immediately and continue with about five cycles of chest compressions and ventilations before activating the emergency ambulance. If two providers are present, one provider should activate the emergency ambulance immediately.

\section{Occupational}

(a) Chemical burns: All contaminated clothing should be immediately removed with care to prevent cross contamination to the first aid provider. Powdered chemicals should be brushed off with a gloved hand or a piece of cloth. Acid or alkali exposure should be irrigated with copious amount of water. ${ }^{(106-112)}$

(b) Toxic eye injury: Eyes exposed to toxic chemicals must be immediately rinsed with copious amount of tap water, (113-118) normal saline or another commercially available eye irrigation solution. ${ }^{(9)}$ This should be continued for at least 15 minutes or until the arrival of the emergency ambulance.

\section{Education}

First aid education should be made universally available. Morbidity and mortality from injury and illness have improved as a result of educational approaches such as online courses, classes with certification and public health campaigns. ${ }^{(19-121)}$ These programmes should focus on prevention, recognition and management of injury and illness. Training guidelines should be developed in the context of first aid settings (e.g. workplace, sports facility). Simpler training courses may be developed for individuals in the home environment. The validity period of the initial training should be determined and providers should undergo a refresher course to maintain competency.

\section{CONCLUSION}

First aid assessments and interventions should be medically sound and grounded on evidence-based medicine. However, as there is a lack of research in the field of first aid, recommendations from ILCOR are extrapolated indirectly from animal, prehospital or hospital-based studies. Therefore, more consolidated research needs to be done in this area. Finally, as the scope of first aid is influenced by training and regulatory requirements, the guidelines contained herein, while specific to the local context, may be refined depending on circumstances and need. The provider must always remember the goals of first aid - to preserve life, alleviate suffering, prevent further illness or injury and promote recovery.

\section{REFERENCES}

1. Zideman DA, Singletary EM, De Buck ED, et al; First Aid Chapter Collaborators. Part 9: First aid: 2015 International Consensus on First Aid Science with Treatment Recommendations. Resuscitation 2015; 95:e225-61.

2. Ministry of Health, Singapore. Principal Causes of Death. Available at: https:// www.moh.gov.sg/content/moh_web/home/statistics/Health_Facts_Singapore/ Principal_Causes_of_Death.html. Accessed July 22, 2015.

3. Ministry of Health, Singapore. Top 10 Conditions of Hospitalisation. Available at: https://www.moh.gov.sg/content/moh_web/home/statistics/Health_Facts_
Singapore/Top_10_Conditions_of_Hospitalisation.html. Accessed December 2, 2015.

4. National First Aid Council, Singapore. Training Framework for Agencies providing child first aid (CFA) courses for personnel in child care centres. 2013. Available at: https://childcarelink.gov.sg/ccls/uploads/Child-First-AidTraining-Framework.pdf. Accessed March 14, 2017.

5. Legislation Division, Attorney-General's Chambers, Republic of Singapore. Workplace Safety and Health Act (Chapter 354A, Section 65), Workplace Safety and Health (First-Aid) Regulations. Revised edition 2007. In: Singapore Statutes Online [online]. Available at: http://statutes.agc.gov.sg/aol/search/ display/view.w3p;ident=ab202a5c-09be-4012-a3da-76dda9536eba;query =Docld\%3Aa7b4b808-d195-44ec-aa3d-dd5b1fa938f3\%20Depth\%3A0\%20 Status\%3Ainforce;rec=0\#pr65-he-. Accessed March 14, 2017.

6. Workplace Safety and Health Council, Ministry of Manpower, Singapore. Technical notes for occupational first aid course (OFAC) part II. Available at: https://www.wshc.sg/files/wshc/upload/cms/file/OFAC_Technical_Notes.pdf. Accessed May 4, 2015.

7. Markenson D, Ferguson JD, Chameides L, et al. Part 17: first aid: 2010 American Heart Association and American Red Cross Guidelines for First Aid. Circulation 2010; 122(18 Suppl 3):S934-46.

8. Singletary EM, Zideman DA, De Buck ED, et al; First Aid Chapter Collaborators. Part 9: First Aid: 2015 International Consensus on First Aid Science with Treatment Recommendations. Circulation 2015; 132(16 Suppl 1):S269-311.

9. Singletary EM, Charlton NP, Epstein JL, et al. Part 15: First Aid: 2015 American Heart Association and American Red Cross Guidelines Update for First Aid. Circulation 2015; 132(18 Suppl 2):S574-89.

10. Karpel JP, Aldrich TK, Prezant DJ, et al. Emergency treatment of acute asthma with albuterol metered-dose inhaler plus holding chamber: how often should treatments be administered? Chest 1997; 112:348-56.

11. Weiss SJ, Anand P, Ernst AA, Orgeron D, May WL. Effect of out-of-hospital albuterol inhalation treatments on patient comfort and morbidity. Ann Emerg Med 1994; 24:873-8.

12. Osmond $\mathrm{MH}$, Klassen TP. Efficacy of ipratropium bromide in acute childhood asthma: a meta-analysis. Acad Emerg Med 1995; 2:651-6.

13. Hermansen MN, Nielsen KG, Buchvald F, et al. Acute relief of exercise-induced bronchoconstriction by inhaled formoterol in children with persistent asthma. Chest 2006; 129:1203-9.

14. Amirav I, Yacobov R, Luder AS. Formoterol turbuhaler is as effective as salbutamol diskus in relieving adenosine-induced bronchoconstriction in children. J Aerosol Med 2007; 20:1-6.

15. Bentur L, Canny GJ, Shields MD, et al. Controlled trial of nebulized albuterol in children younger than 2 years of age with acute asthma. Pediatrics 1992; 89:133-37.

16. Emerman $\mathrm{CL}$, Shade B, Kubincanek J. A controlled trial of nebulized isoetharine in the prehospital treatment of acute asthma. Am J Emerg Med 1990; 8:512-4.

17. Littner MR, Tashkin DP, Siegel SC, Katz R. Double-blind comparison of acute effects of inhaled albuterol, isoproterenol and placebo on cardiopulmonary function and gas exchange in asthmatic children. Ann Allergy 1983; 50:309-16.

18. Berger WE, Milgrom H, Skoner DP, et al; Xopenex Pediatric Asthma Group. Evaluation of levalbuterol metered dose inhaler in pediatric patients with asthma: a double-blind, randomized, placebo- and active-controlled trial. Curr Med Res Opin 2006; 22:1217-26.

19. Politiek MJ, Boorsma M, Aalbers R. Comparison of formoterol, salbutamol and salmeterol in methacholine-induced severe bronchoconstriction. Eur Respir J 1999; 13:988-92.

20. van der Woude HJ, Postma DS, Politiek MJ, Winter TH, Aalbers R. Relief of dyspnoea by beta2-agonists after methacholine-induced bronchoconstriction. Respir Med 2004; 98:816-20.

21. Inoue N, Yamamoto A. Clinical evaluation of pediatric anaphylaxis and the necessity for multiple doses of epinephrine. Asia Pac Allergy 2013; 3:106-14.

22. Järvinen KM, Sicherer SH, Sampson HA, Nowak-Wegrzyn A. Use of multiple doses of epinephrine in food-induced anaphylaxis in children. J Allergy Clin Immunol 2008; 122:133-8.

23. Noimark L, Wales J, Du Toit G, et al. The use of adrenaline autoinjectors by children and teenagers. Clin Exp Allergy 2012; 42:284-92.

24. Korenblat $\mathrm{P}$, Lundie MJ, Dankner RE, Day JH. A retrospective study of epinephrine administration for anaphylaxis: how many doses are needed? Allergy Asthma Proc 1999; 20:383-6.

25. Oren E, Banerji A, Clark S, Camargo CA Jr. Food-induced anaphylaxis and repeated epinephrine treatments. Ann Allergy Asthma Immunol 2007; 99:429-32.

26. Banerji A, Rudders SA, Corel B, et al. Repeat epinephrine treatments for foodrelated allergic reactions that present to the emergency department. Allergy Asthma Proc 2010; 31:308-16.

27. Rudders SA, Banerji A, Corel B, Clark S, Camargo CA Jr. Multicenter study of repeat epinephrine treatments for food-related anaphylaxis. Pediatrics 2010; 125:e711-8.

28. Tsuang A, Menon N, Setia N, Geyman L, Nowak-Wegrzyn AH. Multiple epinephrine doses in food-induced anaphylaxis in children. J Allergy Clin 
Immunol 2013; 131 Suppl: AB90.

29. Rudders SA, Banerji A, Katzman DP, Clark S, Camargo CAJr. Multiple epinephrine doses for stinging insect hypersensitivity reactions treated in the emergency department. Ann Allergy Asthma Immunol 2010; 105:85-93.

30. Randomised trial of intravenous streptokinase, oral aspirin, both, or neither among 17,187 cases of suspected acute myocardial infarction: ISIS-2. ISIS-2 (Second International Study of Infarct Survival) Collaborative Group. Lancet 1988; 2:349-60.

31. Barbash I, Freimark D, Gottlieb S, et al; Israeli working group on intensive cardiac care, Israel heart society. Outcome of myocardial infarction in patients treated with aspirin is enhanced by pre-hospital administration. Cardiology 2002; 98:141-7.

32. Freimark D, Matetzky S, Leor J, et al. Timing of aspirin administration as a determinant of survival of patients with acute myocardial infarction treated with thrombolysis. Am J Cardiol 2002; 89:381-5.

33. Jabot J, Teboul JL, Richard C, Monnet X. Passive leg raising for predicting fluid responsiveness: importance of the postural change. Intensive Care Med 2009; 35:85-90.

34. Wong DH, O'Connor D, Tremper KK, et al. Changes in cardiac output after acute blood loss and position change in man. Crit Care Med 1989; 17:979-83.

35. Lim SH, Wee FC, Chee TS. Basic Cardiac Life Support: 2016 Singapore Guidelines. Singapore Med J 2017; 58:347-53.

36. Litman RS, Wake N, Chan LM, et al. Effect of lateral positioning on upper airway size and morphology in sedated children. Anesthesiology 2005; 103:484-8.

37. Arai YC, Fukunaga K, Hirota S, Fujimoto S. The effects of chin lift and jaw thrust while in the lateral position on stridor score in anesthetized children with adenotonsillar hypertrophy. Anesth Analg 2004; 99:1638-41.

38. Chenkin J, Gladstone DJ, Verbeek PR, et al. Predictive value of the Ontario prehospital stroke screening tool for the identification of patients with acute stroke. Prehosp Emerg Care 2009; 13:153-9.

39. Frendl DM, Strauss DG, Underhill BK, Goldstein LB. Lack of impact of paramedic training and use of the Cincinnati prehospital stroke scale on stroke patient identification and on-scene time. Stroke 2009; 40:754-6.

40. Harbison J, Hossain O, Jenkinson D, et al. Diagnostic accuracy of stroke referrals from primary care, emergency room physicians, and ambulance staff using the face arm speech test. Stroke 2003; 34:71-6.

41. Iguchi Y, Kimura K, Watanabe M, Shibazaki K, Aoki J. Utility of the Kurashiki Prehospital Stroke Scale for hyperacute stroke. Cerebrovasc Dis 2011; 31:51-6.

42. O'Brien W, Crimmins D, Donaldson W, et al. FASTER (Face, Arm, Speech Time, Emergency Response): experience of Central Coast Stroke Service implementation of a pre-hospital notification system for expedient management of acute stroke. J Clin Neurosci 2012; 19:241-5.

43. Wojner-Alexandrov AW, Alexandrov AV, Rodriguez D, Persse D, Grotta JC. Houston paramedic and emergency stroke treatment and outcomes study (HoPSTO). Stroke 2005; 36:1512-8.

44. Slama G, Traynard PY, Desplanque N, et al. The search for an optimized treatment of hypoglycemia. Carbohydrates in tablets, solutin, or gel for the correction of insulin reactions. Arch Intern Med 1990; 150:589-93.

45. Husband AC, Crawford S, McCoy LA, Pacaud D. The effectiveness of glucose, sucrose, and fructose in treating hypoglycemia in children with type 1 diabetes. Pediatr Diabetes 2010; 11:154-8.

46. McTavish L, Wiltshire E. Effective treatment of hypoglycemia in children with type 1 diabetes: a randomized controlled clinical trial. Pediatr Diabetes 2011 12(4 Pt 2):381-7.

47. Brodows RG, Williams C, Amatruda JM. Treatment of insulin reactions in diabetics. JAMA 1984; 252:3378-81.

48. Kenefick RW, O'Moore KM, Mahood NV, Castellani JW. Rapid IV versus ora rehydration: responses to subsequent exercise heat stress. Med Sci Sports Exerc 2006; 38:2125-31.

49. Michell MW, Oliveira HM, Kinsky MP, et al. Enteral resuscitation of burn shock using World Health Organization oral rehydration solution: a potential solution for mass casualty care. J Burn Care Res 2006; 27:819-25.

50. Barclay RL, Depew WT, Vanner SJ. Carbohydrate-electrolyte rehydration protects against intravascular volume contraction during colonic cleansing with orally administered sodium phosphate. Gastrointest Endosc 2002; 56:633-8

51. Currell K, Urch J, Cerri E, et al. Plasma deuterium oxide accumulation following ingestion of different carbohydrate beverages. Appl Physiol Nutr Metab 2008 33:1067-72

52. Jeukendrup AE, Currell K, Clarke J, Cole J, Blannin AK. Effect of beverage glucose and sodium content on fluid delivery. Nutr Metab (Lond) 2009; 6:9.

53. Evans GH, Shirreffs SM, Maughan RJ. Postexercise rehydration in man: the effects of osmolality and carbohydrate content of ingested drinks. Nutrition 2009; 25:905-13.

54. GreenleafJE, Jackson CG, Geelen G, et al. Plasma volume expansion with ora fluids in hypohydrated men at rest and during exercise. Aviat Space Environ Med 1998; 69:837-44.

55. Maughan RJ, Leiper JB. Sodium intake and post-exercise rehydration in man Eur J Appl Physiol Occup Physiol 1995; 71:311-9.
56. Merson SJ, Maughan RJ, Shirreffs SM. Rehydration with drinks differing in sodium concentration and recovery from moderate exercise-induced hypohydration in man. Eur J Appl Physiol 2008; 103:585-94.

57. Shirreffs SM, Taylor AJ, Leiper JB, Maughan RJ. Post-exercise rehydration in man: effects of volume consumed and drink sodium content. Med Sci Sports Exerc 1996; 28:1260-71.

58. Lehmann KG, Heath-Lange SJ, Ferris ST. Randomized comparison of hemostasis techniques after invasive cardiovascular procedures. Am Heart J 1999; 138(6 Pt 1):1118-25.

59. Koreny M, Riedmüller E, Nikfardjam M, Siostrzonek P, Müllner M. Arterial puncture closing devices compared with standard manual compression after cardiac catheterization: systematic review and meta-analysis. JAMA 2004; 291:350-7.

60. Mlekusch W, Dick P, Haumer M, et al. Arterial puncture site management after percutaneous transluminal procedures using a hemostatic wound dressing (Clo-Sur P.A.D.) versus conventional manual compression: a randomized controlled trial. J Endovasc Ther 2006; 13:23-31.

61. Upponi SS, Ganeshan AG, Warakaulle DR, et al. Angioseal versus manual compression for haemostasis following peripheral vascular diagnostic and interventional procedures--a randomized controlled trial. Eur J Radiol 2007; 61:332-4.

62. Simon A, Bumgarner B, Clark K, Israel S. Manual versus mechanical compression for femoral artery hemostasis after cardiac catheterization. Am J Crit Care 1998; 7:308-13.

63. Walker SB, Cleary S, Higgins M. Comparison of the FemoStop device and manual pressure in reducing groin puncture site complications following coronary angioplasty and coronary stent placement. Int J Nurs Pract 2001; 7:366-75

64. Yadav JS, Ziada KM, Almany S, Davis TP, Castaneda F. Comparison of the QuickSeal Femoral Arterial Closure System with manual compression following diagnostic and interventional catheterization procedures. Am J Cardiol 2003; 91:1463-6, A6

65. Naimer SA, Chemla F. Elastic adhesive dressing treatment of bleeding wounds in trauma victims. Am J Emerg Med 2000; 18:816-9.

66. Pillgram-Larsen ], Mellesmo S. [Not a tourniquet, but compressive dressing. Experience from 68 traumatic amputations after injuries from mines]. Tidsskr Nor Laegeforen 1992; 112:2188-90. Norwegian.

67. Naimer SA, Nash M, Niv A, Lapid O. Control of massive bleeding from facial gunshot wound with a compact elastic adhesive compression dressing. Am J Emerg Med 2004; 22:586-8.

68. Naimer SA, Anat N, Katif G; Rescue Team. Evaluation of techniques for treating the bleeding wound. Injury 2004; 35:974-9.

69. Beekley AC, Sebesta JA, Blackbourne LH, et al; 31st Combat Support Hospital Research Group. Prehospital tourniquet use in Operation Iraqi Freedom: effect on hemorrhage control and outcomes. J Trauma 2008; 64(2 Suppl):S28-37; discussion S37.

70. King DR, van der Wilden G, Kragh JF Jr, Blackbourne LH. Forward assessment of 79 prehospital battlefield tourniquets used in the current war. J Spec Oper Med 2012; 12:33-8.

71. Lakstein D, Blumenfeld A, Sokolov $\mathrm{T}$, et al. Tourniquets for hemorrhage control on the battlefield: a 4-year accumulated experience. J Trauma 2003; 54(5 Suppl):S221-5.

72. Kue RC, Temin ES, Weiner SG, et al. Tourniquet use in a civilian emergency medical services setting: a descriptive analysis of the Boston EMS experience. Prehosp Emerg Care 2015; 19:399-404

73. Cox ED, Schreiber MA, MCManus J, Wade CE, Holcomb JB. New hemostatic agents in the combat setting. Transfusion 2009; 49 Suppl 5:248S-55S.

74. Ran Y, Hadad E, Daher S, et al. QuikClot Combat Gauze use for hemorrhage control in military trauma: January 2009 Israel Defense Force experience in the Gaza Strip--a preliminary report of 14 cases. Prehosp Disaster Med 2010; 25:584-8

75. Wedmore I, McManus JG, Pusateri AE, Holcomb JB. A special report on the chitosan-based hemostatic dressing: experience in current combat operations. J Trauma 2006; 60:655-8.

76. Brown MA, Daya MR, Worley JA. Experience with chitosan dressings in a civilian EMS system. J Emerg Med 2009; 37:1-7.

77. Claus EE, Fusco CF, Ingram T, et al. Comparison of the effects of selected dressings on the healing of standardized abrasions. J Athl Train 1998; 33:145-9.

78. Beam JW. Occlusive dressings and the healing of standardized abrasions. J Athl Train 2008; 43:600-7.

79. Hinman CD, Maibach $\mathrm{H}$. Effect of air exposure and occlusion on experimental human skin wounds. Nature 1963; 200:377-8.

80. Yava A, Koyuncu A, Tosun N, Kiliç S. Effectiveness of local cold application on skin burns and pain after transthoracic cardioversion. Emerg Med J 2012; 29:544-9

81. Nguyen NL, Gun RT, Sparnon AL, Ryan P. The importance of immediate cooling--a case series of childhood burns in Vietnam. Burns 2002; 28:173-6.

82. Maroon JC, Mathyssek C, Bost J. Cerebral concussion: a historical perspective. Prog Neurol Surg 2014; 28:1-13. 
83. Davies G, Deakin C, Wilson A. The effect of a rigid collar on intracranial pressure. Injury 1996; 27:647-9.

84. Hunt K, Hallworth S, Smith M. The effects of rigid collar placement on intracranial and cerebral perfusion pressures. Anaesthesia 2001; 56:511-3.

85. Mobbs RJ, Stoodley MA, Fuller J. Effect of cervical hard collar on intracranial pressure after head injury. ANZ J Surg 2002; 72:389-91.

86. Kolb JC, Summers RL, Galli RL. Cervical collar-induced changes in intracranial pressure. Am J Emerg Med 1999; 17:135-7.

87. Raphael JH, Chotai R. Effects of the cervical collar on cerebrospinal fluid pressure. Anaesthesia 1994; 49:437-9.

88. Stone MB, Tubridy CM, Curran R. The effect of rigid cervical collars on internal jugular vein dimensions. Acad Emerg Med 2010; 17:100-2.

89. Dodd FM, Simon E, McKeown D, Patrick MR. The effect of a cervical collar on the tidal volume of anaesthetised adult patients. Anaesthesia 1995; 50:961-3.

90. Coté DJ, Prentice WE Jr, Hooker DN, Shields EW. Comparison of three treatment procedures for minimizing ankle sprain swelling. Phys Ther 1988; 68:1072-6.

91. Meeusen R, Lievens P. The use of cryotherapy in sports injuries. Sports Med 1986; 3:398-414.

92. Hocutt JE Jr, Jaffe R, Rylander CR, Beebe JK. Cryotherapy in ankle sprains. Am J Sports Med 1982; 10:316-9.

93. Airaksinen OV, Kyrklund N, Latvala K, et al. Efficacy of cold gel for soft tissue injuries: a prospective randomized double-blinded trial. Am J Sports Med 2003 31:680-4.

94. Basur RL, Shephard E, Mouzas GL. A cooling method in the treatment of ankle sprains. Practitioner 1976; 216:708-11.

95. Ayata R, Shiraki H, Fukuda T, et al. The effects of icing after exercise on jumper's knee. Jpn J Phys Fitness Sports Med 2007; 56:125-30.

96. Callaham ML. Treatment of common dog bites: infection risk factors. JACEP $1978 ; 7: 83-7$.

97. Mianzan HW, Fenner PJ, Cornelius PF, Ramírez FC. Vinegar as a disarming agent to prevent further discharge of the nematocysts of the stinging hydromedusa Olindias sambaquiensis. Cutis 2001; 68:45-8.

98. Burnett JW, Rubinstein H, Calton GJ. First aid for jellyfish envenomation. South Med J 1983; 76:870-2.

99. Loten C, Stokes B, Worsley D, et al. A randomised controlled trial of hot wate (45 degrees C) immersion versus ice packs for pain relief in bluebottle stings. Med J Aust 2006; 184:329-33

100. Nomura JT, Sato RL, Ahern RM, et al. A randomized paired comparison tria of cutaneous treatments for acute jellyfish (Carybdea alata) stings. Am J Emerg Med 2002; 20:624-6.

101. Yoshimoto CM, Yanagihara AA. Cnidarian (coelenterate) envenomations in Hawai'i improve following heat application. Trans R Soc Trop Med Hyg 2002; 96:300-3.

102. Cegolon L, Heymann WC, Lange JH, Mastrangelo G. Jellyfish stings and their management: A review. Marine Drugs. 2013;11:523-550.

103. Li L, McGee RG, Isbister G, Webster AC. Interventions for the symptoms and signs resulting from jellyfish stings. Cochrane Database of Systematic Reviews. Available at: http://onlinelibrary.wiley.com/doi/10.1002/14651858. CD009688.pub2/abstract. Accessed August 12, 2014

104. Atkinson PR, Boyle A, Hartin D, McAuley D. Is hot water immersion an effective treatment for marine envenomation? Emerg Med J 2006; 23:503-8.

105. Diangelis AJ, Andreasen JO, Ebeleseder KA, et al; International Association of Dental Traumatology. International Association of Dental Traumatology guidelines for the management of traumatic dental injuries: 1 . Fractures and luxations of permanent teeth. Dent Traumatol 2012; 28:2-12.

106. Latenser BA, Lucktong TA. Anhydrous ammonia burns: case presentation and literature review. J Burn Care Rehabil 2000; 21(1 Pt 1):40-2

107. Wibbenmeyer LA, Morgan LJ, Robinson BK, et al. Our chemical burn experience: exposing the dangers of anhydrous ammonia. J Burn Care Rehabil 1999; 20:226-31.

108. Yano K, Hosokawa K, Kakibuchi M, Hikasa H, Hata Y. Effects of washing acid injuries to the skin with water: an experimental study using rats. Burns 1995; 21:500-2.

109. Kono K, Yoshida Y, Watanabe M, et al. An experimental study on the treatment of hydrofluoric acid burns. Arch Environ Contam Toxicol 1992; 22:414-8.

110. Murao M. Studies on the treatment of hydrofluoric acid burn. Bull Osaka Med Coll 1989; 35:39-48

111. Lorette JJ Jr, Wilkinson JA. Alkaline chemical burn to the face requiring fullthickness skin grafting. Ann Emerg Med 1988; 17:739-41.

112. Leonard LG, Scheulen JJ, Munster AM. Chemical burns: effect of prompt first aid. J Trauma 1982; 22:420-3.

113. Kompa S, Schareck B, Tympner J, Wüstemeyer H, Schrage NF. Comparison of emergency eye-wash products in burned porcine eyes. Graefes Arch Clin Exp Ophthalmol 2002; 240:308-13.

114. McCulley JP. Ocular hydrofluoric acid burns: animal model, mechanism of injury and therapy. Trans Am Ophthalmol Soc 1990; 88:649-84.

115. Höjer J, Personne M, Hultén P, Ludwigs U. Topical treatments for hydrofluoric acid burns: a blind controlled experimental study. J Toxicol Clin Toxicol 2002; 40:861-6.

116. Herr RD, White GL Jr, Bernhisel K, Mamalis N, Swanson E. Clinical comparison of ocular irrigation fluids following chemical injury. Am J Emerg Med 1991; 9:228-31.

117. Ingram TA 3rd. Response of the human eye to accidental exposure to sodium hypochlorite. J Endod 1990; 16:235-8

118. Burns FR, Paterson CA. Prompt irrigation of chemical eye injuries may avert severe damage. Occup Health Saf 1989; 58:33-6.

119. Skinner AM, Brown TL, Peat BG, Muller MJ. Reduced hospitalisation of burns patients following a multi-media campaign that increased adequacy of first aid treatment. Burns 2004; 30:82-5.

120. Sunder S, Bharat R. Industrial burns in Jamshedpur, India: epidemiology, prevention and first aid. Burns 1998; 24:444-7.

121. Murad MK, Husum $H$. Trained lay first responders reduce trauma mortality: a controlled study of rural trauma in Iraq. Prehosp Disaster Med 2010· 25:533-9. 